\title{
Chapter 1 \\ Understanding and Tracking Cost of Living, Wages and Purchasing Power for Expatriates and Ordinary Residents
}

\subsection{Background and Research Motivation}

Urbanisation and globalisation are two major forces shaping the world economy. According to the United Nations' estimates, more than half of the world's population now live in urban areas and the proportion of urban dwellers is expected to increase further to 66 percent by $2050 .{ }^{1}$ As a result, the majority of economic activities now take place in cities. Cities currently generate more than 80 percent of global Gross Domestic Product (GDP). ${ }^{2}$ At the same time, due to advances in transportation and communication technologies, economies in different parts of the world have become increasingly interconnected by trade and global production networks. Businesses and people today also enjoy a high degree of global mobility which is unprecedented in human history.

Thus, as cities play an increasingly significant role in driving economic growth, competition among cities has shifted from the national level to a global arena. New York is no longer competing with just San Francisco or Chicago and Shanghai is no longer competing with just Beijing and Guangzhou. In this context, international benchmarks for cities are vital for businesses and individuals to make informed decisions.

In particular, cost of living, wages, and purchasing power are of great interest for employees, employers, multinational corporations (MNCs) and policy-makers. MNCs need to consider cost of living calculations in deciding how best to deploy their human resources around the globe. Meanwhile, ordinary residents are concerned about whether their wages can keep pace with increases in cost of living, especially the costs of housing, transport, education and healthcare. Therefore, for the government of the day, providing high-quality and affordable public services, as well as ensuring broad-based growth in the purchasing power of ordinary residents' wages are important.

While the Consumer Price Index (CPI) may serve as a measure of cost of living at the national level, there is no reliable index which tracks cost of living, wages and purchasing power at the city level yet. Commercial cost of living surveys such as those published by the Economist Intelligent Unit (EIU), Mercer and UBS are only useful as references to calculate compensation for expatriate managers. However, they are inadequate to guide policy analysis, as Section 1.2 will explain in more detail.

\footnotetext{
${ }^{1}$ See United Nations (2014).

${ }^{2}$ See The World Bank (2016).
} 


\subsection{Literature Review}

The theoretical basis of the cost of living index goes as far back as Konus (1939). Pollack (1989); Diewert and Nakamura (1993) and Triplett (2001) also provided useful reviews of the methodological issues surrounding cost of living indices. As defined by Triplett (2001), a cost of living index is a price index that measures the change in consumption costs required to maintain a constant standard of living. The index may include costs of all variables that affect the standard of living, or it may be conditional on some variables that are held constant for the construction of the index. Economists may substitute "standard of living" in the above definition for other jargons such as "constant utility", or as in Blackorby and Russell (1978), the same "indifference surface".

At the national level, national statistical agencies may construct the CPI as a cost of living index though interestingly, this is not always the case. Triplett (2001) told us that while certain countries such as the United States (US) conceptualised the CPI as an indicator reflecting households' cost of living, others drew a sharp distinction between the two. The second position follows from Hill (1997) who argued that the CPI, as an index for measuring inflation, was only designed to capture changes in value of a fixed basket of goods and services with fixed weightages over time. Hill (1997) distinguished this with a cost of living index, which measured differences in value between baskets of goods and services necessary for the consumer to maintain constant utility across time. These baskets might be different from one another, with different weights for the items in the baskets. However, notwithstanding the conceptual debate among segments of the academia, the public, the media, politicians and even academics have long taken to use the CPI as a summary measure for cost of living at the national level.

On the other hand, internationally comparable indices on cost of living and purchasing power at the city level are often published by commercial research houses. These surveys garner a lot of public attention and often generate emotive reactions, especially in the city ranked as the most expensive among its peers. Major commercial studies include the following:

- The UBS Prices and Earnings report, which is published once every three years by the Wealth Management Department of UBS. The report offers indices on price level for expatriates. Gross hourly wages data and purchasing power index and ranking are also available. The basket of goods and services used to calculate the price indices reflects the consumption patterns of a European family of three and the basket is assumed to be common across all cities.

- The EIU Worldwide Cost of Living study, which is updated annually, provides only cost of living indices and rankings for expatriates. The study is based on a single set of international weights for goods and services typically used by the international businessmen. ${ }^{3}$ New York is the base city in this study, with cost of living in other cities benchmarked against it.

- The Mercer annual Cost of Living Survey is now in its $22^{\text {nd }}$ edition. Mercer publishes only the ranking of cities according to the cost of living for expatriates and does not provide any index value.

${ }^{3}$ See http://www.worldwidecostofliving.com/asp/wcol_HelpIndexCalc.asp (accessed on 1 February 2017). 
These commercial reports are designed to aid human resource managers at MNCs in formulating the appropriate compensation policies for expatriate employees on international assignments. Thus, they cannot be used for policy analysis concerning ordinary urban dwellers. This is because expatriates tend to have Western consumption patterns geared towards high-end and lifestyle products and it is unlikely that ordinary residents have the same consumption preferences. Furthermore, in the case of expatriates, it is sensible to assume, as all commercial reports reviewed above tend to do, a common consumption pattern due to the social settings associated with the nature of expatriates' work as foreign white-collar professionals. However, this assumption does not hold for ordinary residents, whose consumption patterns vary according to their geographical location, social values and cultural affiliations. As a result, drawing conclusion about a "general" cost of living level based on commercial researches risks overstating significantly the true cost of living for ordinary residents.

Commercial studies may also suffer from serious methodological weaknesses and data inaccuracies. For instance, as pointed out by Tan and Luu (2016), there were considerable discrepancies in the data used in the 2009 UBS Prices and Earnings report which overstated the cost of living in Singapore even for expatriates. In that report, prices for home electronics and household appliances in Singapore were above that of Mumbai, which was counterintuitive as visitors from India tend to spend twice as much on electronics as the average tourist in Singapore. ${ }^{4}$ On restaurants, the 2009 UBS report put Singapore's price level slightly above that of many Western European cities, including Paris, which are known for their expensive restaurant meals. ${ }^{5}$

More importantly, the same study has made some simplistic assumptions in calculating its reported indices and rankings and these assumptions turned out to be problematic. UBS has, for instance, used a common occupation profile, based on global averages, to derive the average wage in each city. Nevertheless, this occupation profile severely understated the percentage of Professionals, Managers, Executives \& Technicians (PMETs) and overstated the share of Production, Transportation Operators and General Labours (PTOGLs) and Clerical, Sales \& Service Workers (CSRWs) in Singapore. The percentage of PMETs assumed by UBS in the 2009 report, which was made available upon request, was 9 percent. This was much lower than Singapore's actual percentage of PMETs in the resident workforce in 2009 at 52 percent as reported by the Singapore's Ministry of Manpower. ${ }^{6}$ Meanwhile, Singapore residents' shares of PTOGLs and CSRWs in 2009 were both 24 percent, ${ }^{7}$ lower than UBS' assumed figures at 58 percent and 33 percent, respectively. Because of these mismatches, the 2009 UBS report understated the average wage levels in Singapore. ${ }^{8}$ When divided by the UBS' cost of living index

\footnotetext{
${ }^{4}$ See Singapore Tourism Board (2013).

${ }^{5}$ See UBS Wealth Management Research Department (2009).

${ }^{6}$ See Ministry of Manpower (2009).

${ }^{7}$ Ibid.

${ }^{8}$ The UBS also appeared to have excluded contributions to the Central Provident Fund (CPF) — Singapore's defined contribution social security system — from their calculation of wages. This exacerbated the understatement of wages in Singapore because CPF contributions are also used extensively for housing, medical and educational expenses prior to retirement. Hence, they should be treated as part of wages. See Tan and Luu (2016) for a detailed discussion.
} 
which overstated the true cost of living in Singapore, the net result is that the purchasing power in the city-state was severely understated. ${ }^{9}$

The UBS research is not the only commercial study fraught with methodological problems. We also suspect that the cost of living rankings reported in the annual EIU Worldwide Cost of Living survey are sensitive to the choice of the base city. This means that the ranking results would change if the EIU used Tokyo or London instead of New York as the benchmark city to compute their cost of living index. In response to our queries, the EIU has said that "the reality is that the availability of goods and services and factors like rounding of numbers means that rebasing a city will produce slightly different results". ${ }^{10}$ This is not a satisfactory explanation. Rounding errors may produce different index values but the rankings of cities depend critically on the ratios of the index values of the cities being compared, which by right should remain unchanged when the base city is switched. Sensitivity of the ranking results to the choice of base city calls into question the rigour of the research, as this means that the research results are not consistent and open to manipulation. ACI's rankings of cost of living, wages and purchasing power do not suffer from such pitfalls. ${ }^{11}$

The discussion above serves to highlight that it is not advisable to use commercial research reports for purposes other than their intended role as references to design expatriates' compensation packages. In fact, given the prevalence of methodological and data problems in these studies, one should even exercise caution when using them for making inferences about expatriates' cost of living. Meanwhile, existing academic literature has not adequately addressed the issue of measuring cost of living at the city level. This is a gap that the ACI intends to fill with our research.

\subsection{Factors which Affect Cost of Living, Wages and Purchasing Power for Expatriates and Ordinary Residents}

Obtaining reliable international benchmarks on cost of living, wages and purchasing power is important as they facilitate meaningful analyses into issues affecting expatriate and ordinary urban dwellers. With this objective, the Asia Competitiveness Institute (ACI) at the Lee Kuan Yew School of Public Policy (LKYSPP), National University of Singapore (NUS) has developed comprehensive indices which systematically track cost of living for expatriates as well as cost of living, wages and purchasing power for ordinary residents across the world's major cities since 2005. This section summarises some important insights which can be gained from examining our indices. These include differences in the geographical distributions of cities according to their cost of living for ordinary residents and cost of living for expatriates; the sensitivity of cost of living ranking to exchange rate fluctuations and the relationships between cost of living, purchasing power and liveability of cities.

\footnotetext{
${ }^{9} \mathrm{Tan}$ and Gu (2011) and Tan and Vu (2011) have revised the 2009 UBS estimates for Singapore using appropriate methodologies and data. They found significant differences with the original results.

${ }^{10}$ Jon Copestake, email to ACI staff Yuan Randong, 8 September, 2014.

${ }^{11}$ See Section 2.6 in Chapter 2 for a more detailed discussion.
} 


\subsubsection{Geographical Distributions of Cities According to Cost of Living for Expatriates and Cost of Living for Ordinary Residents}

From our research, we have observed that Western cities tend to have higher cost of living for ordinary residents than cities in other parts of the world. On the other hand, there is no pattern in the geographical distribution of the cities according to their cost of living for expatriates. This means that ordinary residents in an Asian city, such as Seoul, are likely to face lower cost of living than their counterparts in a Western European city such as Paris. However, it is not possible to make any a priori conjecture about how the cost of living for expatriates in the former may compare with that in the latter.

Figures 1.1 and 1.2 illustrate the geographical distributions of the 103 cities we have studied according to their costs of living for ordinary residents and expatriates, respectively. The figures reflect the latest index results which are based on 2014 data. In both figures, the longer the bar, the higher the cost of living index value and hence the more expensive the city for ordinary residents or expatriates, respectively.

Similar to the previous edition of our research based on 2013 data, ${ }^{12}$ we found that cities in Western Europe, Australasia and North America were relatively expensive for ordinary residents in 2014. In contrast, African and Asian cities were the cheapest for ordinary residents, followed by Eastern European cities and cities in South America (see Figure 1.1). Tel Aviv, Tokyo, Caracas, Osaka-Kobe, and Singapore were the few exceptions: Tokyo and Tel Aviv were slightly more expensive than Washington DC while the cost of living in Caracas was slightly higher than that in Rome. Meanwhile, costs of living for ordinary residents in Osaka-Kobe and Singapore were greater than that in Pittsburgh and Lisbon, respectively.

In contrast, Figure 1.2 shows no discernible pattern in the distribution of cities according to the cost of living for expatriates.

That cities in the West are more expensive for ordinary residents than cities elsewhere in the world is due to differences in the cost structure of non-traded goods and services among these cities. In particular, locally provided services which are non-traded either form an integral part of ordinary residents' consumption baskets or go into the local production and provision of other goods consumed by ordinary residents. These services, by nature, are labour-intensive and the labour costs in Western Europe, Australasia and North America are significantly higher than that in Africa, Asia, Eastern Europe and South America. For instance, the average gross hourly wage in all Western European cities in our study in 2014 was 26.9 US dollars as compared to 7.0 US dollars for Asian cities. Such wage differentials lead to higher prices for products and services, hence higher overall cost of living for ordinary residents in Western cities. It should be noted, however, that because of higher wages, ordinary residents' purchasing power in the West is also generally higher than their counterparts elsewhere in the world despite the high cost of living. ${ }^{13}$

Exceptions for Tel Aviv, Tokyo, Osaka-Kobe and Singapore as shown in Figure 1.1 simply reflect comparability of labour costs in these cities and their Western counterparts. This is because these cities are at similar development stages as the Western cities, with similar levels

\footnotetext{
${ }^{12}$ See Chapter 6 in Tan et al. (2015).

${ }^{13}$ See Chapter 6 for more details.
} 
Figure 1.1: ACI's Cost of Living Index for Ordinary Residents across 103 World's Major Cities in 2014 by Geographical Regions

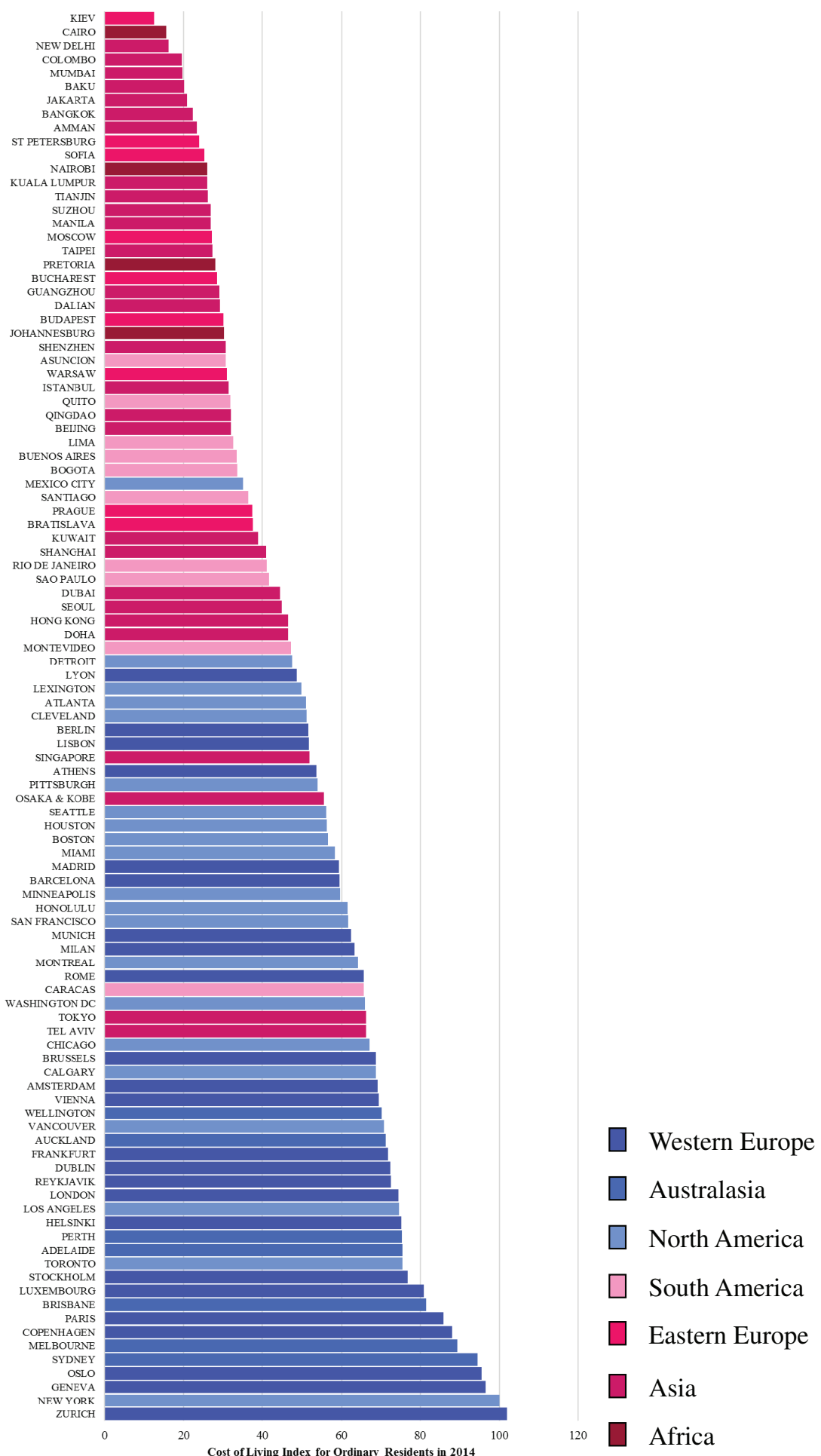

Source: Asia Competitiveness Institute 
Figure 1.2: ACI's Cost of Living Index for Expatriates across 103 World's Major Cities in 2014 by Geographical Regions

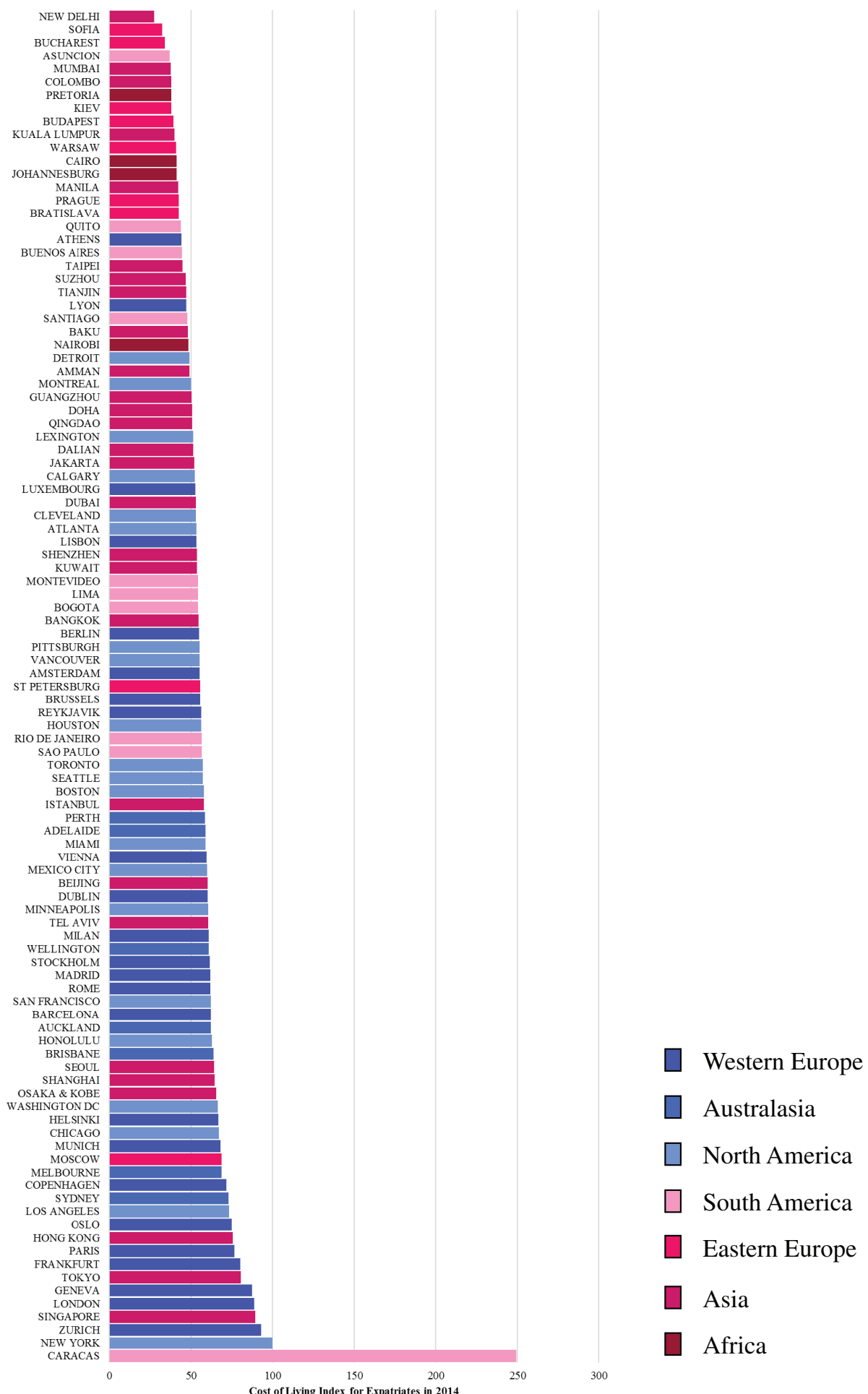


of labour productivity. Meanwhile, abnormally high cost of living in Caracas in 2014 was the result of macroeconomic instability especially the inflation-depreciation spiral which has happened in Venezuela.

On the other hand, expatriates everywhere are geared towards high-end imports and lifestyle products. As such, their cost of living is mainly affected by exchange rate fluctuations and other factors driving the costs of trade rather than local factors. This explains the lack of pattern in the geographical distribution of cities according to the cost of living for expatriates.

These findings again underscore the importance of distinguishing the analyses on expatriates and ordinary residents. Conflating the latter with the former risks overstating ordinary residents' cost of living in developing countries, especially in Asia. Furthermore, the findings also imply that Western expatriates posted to Asia and other regions outside the Western world will benefit if they start to adopt the lifestyles and consumption patterns of ordinary residents in the local cities.

\subsubsection{Sensitivity of Cost of Living Rankings to Exchange Rate Fluctuations}

Next, we consider a more technical issue which is the sensitivity of cost of living rankings to exchange rate fluctuations. In any study which endeavours to make international comparison of cost of living across different cities, the price data used must always be converted to a common unit of measurement. ACI's study, as with most other studies, uses the US dollar as the common currency for conversion. However, the side effect of conversion is that the exchange rates of various currencies are integrated into the calculations of the cost of living indices. As a result, the index value, and by extension the ranking of a city, reflects not only the relative expensiveness of that city with respect to its peers, but also the relative strength of its currency vis-à-vis the common currency. Exchange rate fluctuations therefore influence cost of living rankings. For instance, currency appreciation may help to push the ranking of a city upward as generic increases in local prices over the study period will be magnified during currency conversion.

In the previous edition of the research, we have conducted a simulation for Singapore and Hong Kong to illustrate this effect. The baseline scenario of the simulation was one where exchange rates against the US dollar in all cities followed their actual trajectories throughout the period 2005-2013. On the other hand, in the simulation scenario, exchange rates of all other cities still traced out their actual fluctuations but exchange rate in the city of interest, that is, either Singapore or Hong Kong, was kept at its 2005 levels. The simulated cost of living rankings for expatriates and ordinary residents in these two cities were then compared with their actual rankings. ${ }^{14}$ Tables 1.1 and 1.2 provide an update of this simulation, incorporating the latest results based on 2014 data.

Between 2005 and 2014, the Singapore dollar appreciated by about 24 percent against the US dollar as the exchange rate went from 1.664 Singapore dollars per US dollar in 2005 to 1.267

\footnotetext{
${ }^{14}$ See Chapter 6 in Tan et al. (2015) for more details on the simulation methodology.
} 
Table 1.1: Actual and Simulated Cost of Living Rankings for Expatriates in Singapore and Hong Kong, 2005-2014

\begin{tabular}{lcccccccccc}
\hline & $\mathbf{2 0 0 5}$ & $\mathbf{2 0 0 6}$ & $\mathbf{2 0 0 7}$ & $\mathbf{2 0 0 8}$ & $\mathbf{2 0 0 9}$ & $\mathbf{2 0 1 0}$ & $\mathbf{2 0 1 1}$ & $\mathbf{2 0 1 2}$ & $\mathbf{2 0 1 3}$ & $\mathbf{2 0 1 4}$ \\
\hline $\begin{array}{l}\text { Singapore's Cost of Living } \\
\quad \text { Ranking for Expatriates }\end{array}$ & 15 & 13 & 12 & 12 & 12 & 10 & 8 & 7 & 4 & 4 \\
$\begin{array}{l}\text { Singapore's Simulated Cost of } \\
\quad \text { Living Ranking for Expatriates }\end{array}$ & - & 15 & 21 & 31 & 25 & 24 & 33 & 22 & 24 & 16 \\
$\begin{array}{l}\text { Hong Kong's Cost of Living } \\
\quad \text { Ranking for Expatriates }\end{array}$ & 5 & 6 & 10 & 17 & 13 & 12 & 12 & 9 & 11 & 10 \\
$\begin{array}{l}\text { Hong Kong's Simulated Cost of } \\
\quad \text { Living Ranking for Expatriates }\end{array}$ & - & 7 & 10 & 17 & 13 & 12 & 12 & 9 & 11 & 10 \\
$\begin{array}{l}\text { Singapore Dollar per US Dollar } \\
\quad \text { Yearly Average Exchange Rate }\end{array}$ & 1.664 & 1.589 & 1.507 & 1.415 & 1.454 & 1.363 & 1.257 & 1.249 & 1.251 & 1.267 \\
$\begin{array}{c}\text { Hong Kong Dollar per US Dollar } \\
\quad \text { Yearly Average Exchange Rate }\end{array}$ & 7.777 & 7.768 & 7.802 & 7.786 & 7.752 & 7.769 & 7.784 & 7.757 & 7.757 & 7.755 \\
\hline
\end{tabular}

Note: Yearly average exchange rates are calculated from Bloomberg's daily exchange rate data. See Chapters 2 and 3 for more details. Source: Asia Competitiveness Institute

Table 1.2: Actual and Simulated Cost of Living Rankings for Expatriates in Singapore and Hong Kong, 2005-2014

\begin{tabular}{|c|c|c|c|c|c|c|c|c|c|c|}
\hline & 2005 & 2006 & 2007 & 2008 & 2009 & 2010 & 2011 & 2012 & 2013 & 2014 \\
\hline $\begin{array}{l}\text { Singapore's Cost of Living } \\
\text { Ranking for Ordinary } \\
\text { Residents }\end{array}$ & 58 & 60 & 59 & 56 & 59 & 53 & 55 & 48 & 48 & 49 \\
\hline $\begin{array}{l}\text { Singapore's Simulated Cost of } \\
\text { Living Ranking for Ordinary } \\
\text { Residents }\end{array}$ & - & 60 & 62 & 65 & 62 & 64 & 69 & 66 & 67 & 64 \\
\hline $\begin{array}{l}\text { Hong Kong's Cost of Living } \\
\text { Ranking for Ordinary } \\
\text { Residents }\end{array}$ & 56 & 58 & 60 & 62 & 60 & 62 & 63 & 62 & 59 & 59 \\
\hline $\begin{array}{l}\text { Hong Kong's Simulated Cost of } \\
\text { Living Ranking for Ordinary } \\
\text { Residents }\end{array}$ & - & 58 & 60 & 62 & 60 & 62 & 63 & 62 & 59 & 59 \\
\hline $\begin{array}{l}\text { Singapore Dollar per US Dollar } \\
\text { Yearly Average Exchange Rate }\end{array}$ & 1.664 & 1.589 & 1.507 & 1.415 & 1.454 & 1.363 & 1.257 & 1.249 & 1.251 & 1.267 \\
\hline $\begin{array}{l}\text { Hong Kong Dollar per US Dollar } \\
\text { Yearly Average Exchange Rate }\end{array}$ & 7.777 & 7.768 & 7.802 & 7.786 & 7.752 & 7.769 & 7.784 & 7.757 & 7.757 & 7.755 \\
\hline
\end{tabular}

Note: Yearly average exchange rates are calculated from Bloomberg's daily exchange rate data. See Chapters 2 and 3 for more details.

Source: Asia Competitiveness Institute 
Singapore dollars per US dollar in 2014. Concurrently, Singapore's Cost of Living Ranking for Expatriates rose from $15^{\text {th }}$ to fourth while its Cost of Living Ranking for Ordinary Residents moved up from $58^{\text {th }}$ in 2005 to $53^{\text {rd }}$ in 2010 and then climbed from $55^{\text {th }}$ to $48^{\text {th }}$ between 2011 and 2014. ${ }^{15}$ However, as Table 1.1 demonstrates, if the Singapore dollar had maintained its 2005 exchange rate against the US dollar throughout the study period, its Cost of Living Ranking for Expatriates would have dropped from $15^{\text {th }}$ in 2005 to $16^{\text {th }}$ in 2014 . At the same time, as shown in Table 1.2, Singapore's Cost of Living Ranking for Ordinary Residents would have dropped from $60^{\text {th }}$ in 2005 to $64^{\text {th }}$ in 2010 and risen modestly from $69^{\text {th }}$ in 2011 to $64^{\text {th }}$ in 2014 . Furthermore, Singapore's simulated cost of living rankings, for both expatriates and ordinary residents, are always lower than its actual ranking positions. Clearly, the strong Singapore dollar has helped to push Singapore's rankings upward.

In contrast, Hong Kong's simulated rankings for both expatriates and ordinary residents are almost always identical to its actual rankings. In fact, there is no difference between the simulated and actual Cost of Living Rankings for Ordinary Residents in Hong Kong throughout 2005-2014. For expatriates, Hong Kong's simulated and original rankings are also the same for all years except for 2006 when the two differ by only one place. This is hardly surprising. The Hong Kong dollar is pegged against the US dollar, which means that there were little fluctuations in Hong Kong's exchange rate with the US dollar to significantly affect its actual ranking results in the first place.

This simple simulation exercise demonstrates the effect that exchange rate movements in a particular city may have on its cost of living rankings. However, exchange rate fluctuations in other cities may also influence the rankings of the city of interest. Consider, for example, the case of Singapore for the period 2011-2014. Singapore's Cost of Living Ranking for Ordinary Residents climbed six places from $55^{\text {th }}$ in 2011 to $49^{\text {th }}$ in 2014 , overtaking Atlanta, Buenos Aires, Rio de Janeiro, Lyon, Pittsburgh, Lexington, Berlin and Lisbon. Over the same period, the exchange rate of the Singapore dollar against the US dollar was rather stable, with the Singapore dollar appreciating by only 0.8 percent between 2011 and 2014. In contrast, the Euro depreciated by 4.9 percent against the US dollar; the Brazilian real depreciated by 40.6 percent and the Argentinian peso depreciated by 96.7 percent. These depreciation episodes helped to dampen increases in local prices in Lyon, Berlin, Lisbon, Rio de Janeiro and Buenos Aires over 20112014 when the prices were converted to US dollar. On the other hand, the upward trends of local prices in Singapore were almost fully preserved after conversion. This disparity contributed to the rise of Singapore's ranking over the mentioned cities.

A similar observation can be made for the Cost of Living Ranking for Expatriates. Over 2011-2014, Singapore's Cost of Living Ranking for Expatriates rose from eighth to fourth. In the process, it overtook Oslo, Frankfurt, Osaka-Kobe, London, Geneva and Tokyo. Again, this was partly the result of exchange rate movements in these cities. From 2011 to 2014, the

\footnotetext{
${ }^{15}$ The ACI Cost of Living Index and Ranking for Ordinary Residents were constructed using data from two different rounds of World Bank International Comparison Program survey in 2005 and 2011. Thus, for a more precise analysis of the ranking, we need to split the study period into two sub-periods: 2005-2010 and 2011-2014. See Section 3.4.2 in Chapter 3 for a more detailed discussion.
} 
Norwegian krone, which is the local currency in Oslo, depreciated by 12.5 percent against the US dollar; the Japanese yen, which is the local currency in Osaka-Kobe and Tokyo, depreciated by 32.9 percent and the Swiss franc in Geneva depreciated by 3.3 percent. Meanwhile, the local currency of Frankfurt is the Euro, which as noted, also depreciated by 4.9 percent between 2011 and 2014.

However, there is an exception: Singapore rose above London in Cost of Living Ranking for Expatriates between 2011 and 2014, despite a 2.7 percent appreciation of the British pound against the US dollar over this period. This serves to remind us that while important, exchange rate fluctuations are only one among many factors contributing to changes in cost of living rankings. The strength of the exchange rate effect depends on the extent to which exchange rate movements complement or hinder the actual dynamics of local prices.

\subsubsection{The Effects of Currency Appreciation on Expatriates and Ordinary Residents}

Technicalities about the cost of living rankings aside, exchange rate fluctuations have real effects on the welfare of expatriates and ordinary residents. To make the discussion tractable, we examine a specific scenario whereby the Singapore dollar appreciates in a sustained manner against the currencies of its trading partners.

As the Singapore dollar strengthens against other currencies, it requires fewer Singapore dollars to buy one unit of foreign currency worth of imports. Consequently, there is downward pressure on local, Singapore dollar-denominated prices of imports. Consumption items which are imported may therefore become cheaper in Singapore. This is beneficial for both expatriates and ordinary residents, but especially so for the former because expatriates are geared towards consuming high-end imported products. At the same time, prices of locally produced goods which have imports as close substitutes are also likely to decrease because of competitive pressure. Goods which use imports as intermediate inputs in their production may also decrease in prices, further resulting in gains for expatriate and ordinary resident consumers.

However, the transmission of exchange rate shocks to retail prices of imported goods is not a one-to-one correspondence. In other words, a one percent appreciation in the Singapore dollar may only result in a less than one percent decrease in import prices. There are at least two reasons for this. Firstly, the linkages between exchange rate fluctuations and local prices of imports as set by importers also depend on the market structure of the market for imports, government's exchange rate policy and the vagaries of the business cycles. Chew et al. (2011), for example, has showed that importers exhibited asymmetric behaviour in passing on cost saving resulted from a stronger exchange rate over the business cycle: given an appreciation of the Singapore dollar, importers are likely to reduce local import prices by a lesser degree amidst robust economic growth than during a downturn. Secondly, imported goods also contain value added from locally provided services such as transport, logistics, wholesaling and retailing as they are delivered to the consumers. These services are non-traded and as such their costs are not sensitive to exchange rate movements. Therefore, the effect of exchange rate on the final retail prices of imports is further weakened. 
On the other hand, a strong Singapore dollar makes the prices of Singapore's exports less competitive. Thus, international demands for Singapore's exports are likely to be reduced. The precise magnitude of the effect of course depends on how much the appreciation is transmitted to local retail prices of Singapore exports overseas. More importantly, it also depends on price elasticity of overseas demand for Singapore's exports. If demand is relatively inelastic, the decrease in quantities demanded will be marginal. However, if the reverse is true, the slump in exports will be great and this may have serious repercussions for the employment prospects of ordinary residents working in export sectors in Singapore.

Notwithstanding the above argument, a strong Singapore dollar does not have a direct bearing on ordinary residents' income and wealth. Most ordinary residents are remunerated in Singapore dollar so fluctuations of the currency do not affect the value of their income. Also, since ordinary residents tend to save and invest in local assets, such as Singapore dollar-denominated time deposits or savings with the $\mathrm{CPF}$, the value of their wealth also remains unaffected by exchange rate movements. Only the upper strata of the population may be affected as the value of any foreign assets they hold in terms of the Singapore dollar will decrease as the currency appreciates.

In contrast, a strong Singapore dollar has an income effect on expatriates, though the exact nature of the effect depends on their remuneration arrangements. If an expatriate is paid in his home currency or in US dollar, the value of his income in terms of Singapore dollar may decrease. On the other hand, if the expatriate is compensated in Singapore dollar, the value of his income is not reduced. In fact, the appreciation of the Singapore dollar may even be beneficial for expatriates who are paid in the currency. This is because expatriates often remit a portion of their income back home, either to support dependants or to meet outstanding financial commitments such as mortgages. A strong Singapore dollar lessens the burden of remittances, as the same amount of foreign currency can be sent using fewer Singapore dollars. Therefore, more income is made available for consumption.

These conclusions are important as bases to reinforce, justify or fine-tune existing exchange rate policies in economies which maintain a managed float exchange rate regime like Singapore. Letting the currency appreciate may help to mitigate imported inflation, but such policy can only be properly conducted if there are accurate estimations of pass-through effects of exchange rate fluctuations to domestic prices. At the same time, the need to manage inflation must be balanced against other objectives as a strong currency may hamper exporting activities. Finally, the presence of income effect of exchange rate fluctuations on expatriates means that exchange rate policies also affect a city's ability to attract global talents.

\subsubsection{Relationships between Cost of Living, Purchasing Power and Liveability}

Reliable indices also allow us to examine the relationships between cost of living, purchasing power and liveability - three interrelated dimensions contributing to urban dwellers' quality of life. Following the influential contributions of Florida (2002), a strand of urbanisation literature has emerged which recognised cities' role as hubs for creativity and innovation which drive 
economic growth for the entire country. In this context, the literature emphasised the need for cities to attract and retain high quality human capital, especially those whom Florida (2002) referred to as the "creative class", by providing them with good quality of life. While there is no consensus on a common definition on what "quality of life" should stand for, several studies have attempted to identify its different characteristics. ${ }^{16}$ Beyond conventional academic researches, the idea of quality of life has also caught on among private and consulting organisations which often produce quality of life rankings for global cities. At the same time, improving ordinary residents' quality of life has also become the "rallying cry of many big-city mayors" around the globe. ${ }^{17}$

The two dimensions of quality of life that usually receive the most attention from the public and policy-makers are liveability and cost of living. The first encompasses city-specific characteristics which make the city's denizens feel that it is worth living in. The second measures how expensive the city is. While it is easy to define and measure cost of living, liveability is a fluid concept. Nonetheless, one may conceptualise liveable city as one which provides ordinary residents with good jobs, high-quality and accessible public services as well as a safe and clean living environment. Liveability can also be understood from the perspective of individuals' freedoms, in the same spirit with Roosevelt's 1941 State of the Union Address which espoused on four basic human freedoms including freedom from want, freedom from fear, freedom to worship, and freedom of speech. ${ }^{18}$ Given that life in a liveable city is highly desirable, a natural question is that whether liveability comes at a premium. In other words, are liveable cities also expensive to live in?

This question is the main subject of inquiry in Chapter 6 of this book. In addition, we also investigate the relationship between liveability and purchasing power. While cost of living is no doubt important, purchasing power is even more crucial to ordinary residents' welfare as it reflects the extent to which ordinary residents' wages can match up to their cost of living. Ordinary residents who live in a city with high cost of living may still be able to afford life in that city if they also earn high wages. Therefore, in Chapter 6, we also benchmark liveability against purchasing power for a holistic analysis.

\subsection{Expected Contributions of ACl's Study and Chapter Organisation of the Book}

This book provides a valuable compendium of annual indices and rankings of cost of living for expatriates and cost of living, wages and purchasing power for ordinary residents in 103 world's major cities over the period 2005-2014. Now in its second edition, ${ }^{19}$ ACI's study reflects salient differences in costs of living for expatriate and ordinary urban dwellers which arise from variations in their lifestyles and consumption preferences. This is of critical significance as cost of

\footnotetext{
${ }^{16}$ See Rogerson (1999) and Hasan (2007) and references cited within for an overview of this literature.

${ }^{17}$ See Hasan (2007).

${ }^{18}$ See Chapter 5 in Tan et al. (2017, forthcoming).

${ }^{19}$ See Tan et al. (2015) for the first edition of the study, which utilises data between 2005 and 2013.
} 
living for the former is usually conflated as that for the latter by the general public. We believe that ACI's pioneering attempt is the first ever comprehensive study on ordinary residents available today. As for expatriates, cost of living researches are widely available but as reviewed in Section 1.2, these are conducted in a much less rigorous manner than ACI's study.

The publication of this book represents a colossal undertaking combining leading edge research with rigorous methodology and datasets which are disclosed openly. Weights employed for consumption baskets are justified across different continents and stated explicitly. Moreover, all assumptions made are also laid down in a transparent manner. It is our belief that unless assumptions, methodology and data sources are disclosed publicly for open scrutiny, non-rigorous studies will mushroom, spreading spurious and misleading results.

This book is of interest to various parties. The findings in this book allow MNC employers to review and adjust compensation packages for expatriates, making them more competitive based on differences between expatriates' and ordinary residents' costs of living. For academics, the ACI research delivers more accurate depictions of costs of living at the city level. The distinction made between ordinary residents and expatriates opens up more tools for social research. Finally, for policy-makers looking to make city life better for ordinary residents, our indices provide a reliable way to track ordinary residents' cost of living, and more importantly whether ordinary residents' purchasing power has increased over time. Poverty statistics can also be measured differently by taking into account the cost of living of ordinary residents. Finally, the analyses presented through our case studies yield important policy implications.

The world's major 103 cities covered by ACI's study are located all over the globe, including cities in Africa, Asia, Australasia, Western and Eastern Europe, North and South America. The list of cities is shown in Table 1.3.

The rest of the book is organised as follows. Chapter 2 discusses at length the methodology on cost of living for expatriates, presenting data sources including prices and weights used where assumptions made are also explicitly stated. The method to construct the overall Cost of Living Index and Ranking for Expatriates, as well as indices and rankings specific to each ACI Consumption Category is spelt out in detail.

Chapter 3 describes the methodology on cost of living, wages and purchasing power for ordinary residents where components of adjustment factors such as inflation rates, nominal expenditure and real expenditure per capita are highlighted. The construction of the overall Cost of Living Index and Ranking for Ordinary Residents, together with category-specific cost indices and rankings, is elaborated painstakingly. The computation of the Wages Index and Ranking for ordinary residents involving gross average nominal monthly wages and mean weekly hours actually worked is also illustrated step-by-step. Finally, the chapter describes the methodology used to construct the Purchasing Power Index and Ranking for Ordinary Residents from the cost of living and wage indices.

Chapter 4 presents findings pertaining to the Cost of Living Ranking for Expatriates in the 103 cities. It first highlights the latest ranking positions for the top- and bottom-25 percent cities based on data for 2014. Next, it describes some notable observations regarding the rankings for expatriates for each region covered in the study before zooming in to the major global financial centres which include London, New York, Hong Kong, Singapore, Tokyo and Zurich. Finally, 
Table 1.3: List of Cities Covered by the ACI Annual Indices on Cost of Living, Wages and Purchasing Power

\begin{tabular}{|c|c|c|c|}
\hline No. & City & Country & Region \\
\hline 1 & Adelaide & Australia & Australasia \\
\hline 2 & Amman & Jordan & Asia \\
\hline 3 & Amsterdam & Netherlands & Western Europe \\
\hline 4 & Asuncion & Paraguay & South America \\
\hline 5 & Athens & Greece & Western Europe \\
\hline 6 & Atlanta & United States & North America \\
\hline 7 & Auckland & New Zealand & Australasia \\
\hline 8 & Baku & Azerbaijan & Asia \\
\hline 9 & Bangkok & Thailand & Asia \\
\hline 10 & Barcelona & Spain & Western Europe \\
\hline 11 & Beijing & China & Asia \\
\hline 12 & Berlin & Germany & Western Europe \\
\hline 13 & Bogota & Colombia & South America \\
\hline 14 & Boston & United States & North America \\
\hline 15 & Bratislava & Slovakia & Eastern Europe \\
\hline 16 & Brisbane & Australia & Australasia \\
\hline 17 & Brussels & Belgium & Western Europe \\
\hline 18 & Bucharest & Romania & Eastern Europe \\
\hline 19 & Budapest & Hungary & Eastern Europe \\
\hline 20 & Buenos Aires & Argentina & South America \\
\hline 21 & Cairo & Egypt & Africa \\
\hline 22 & Calgary & Canada & North America \\
\hline 23 & Caracas & Venezuela & South America \\
\hline 24 & Chicago & United States & North America \\
\hline 25 & Cleveland & United States & North America \\
\hline 26 & Colombo & Sri Lanka & Asia \\
\hline 27 & Copenhagen & Denmark & Western Europe \\
\hline 28 & Dalian & China & Asia \\
\hline 29 & Detroit & United States & North America \\
\hline 30 & Doha & Qatar & Asia \\
\hline 31 & Dubai & United Arab Emirates & Asia \\
\hline 32 & Dublin & Ireland & Western Europe \\
\hline 33 & Frankfurt & Germany & Western Europe \\
\hline 34 & Geneva & Switzerland & Western Europe \\
\hline 35 & Guangzhou & China & Asia \\
\hline
\end{tabular}


Table 1.3: (Continued)

\begin{tabular}{|c|c|c|c|}
\hline No. & City & Country & Region \\
\hline 36 & Helsinki & Finland & Western Europe \\
\hline 37 & Hong Kong & Hong Kong, China & Asia \\
\hline 38 & Honolulu & United States & North America \\
\hline 39 & Houston & United States & North America \\
\hline 40 & Istanbul & Turkey & Asia \\
\hline 41 & Jakarta & Indonesia & Asia \\
\hline 42 & Johannesburg & South Africa & Africa \\
\hline 43 & Kiev & Ukraine & Eastern Europe \\
\hline 44 & Kuala Lumpur & Malaysia & Asia \\
\hline 45 & Kuwait City & Kuwait & Asia \\
\hline 46 & Lexington & United States & North America \\
\hline 47 & Lima & Peru & South America \\
\hline 48 & Lisbon & Portugal & Western Europe \\
\hline 49 & London & Great Britain & Western Europe \\
\hline 50 & Los Angeles & United States & North America \\
\hline 51 & Luxembourg & Luxembourg & Western Europe \\
\hline 52 & Lyon & France & Western Europe \\
\hline 53 & Madrid & Spain & Western Europe \\
\hline 54 & Manila & Philippines & Asia \\
\hline 55 & Melbourne & Australia & Australasia \\
\hline 56 & Mexico City & Mexico & North America \\
\hline 57 & Miami & United States & North America \\
\hline 58 & Milan & Italy & Western Europe \\
\hline 59 & Minneapolis & United States & North America \\
\hline 60 & Montevideo & Uruguay & South America \\
\hline 61 & Montreal & Canada & North America \\
\hline 62 & Moscow & Russia & Eastern Europe \\
\hline 63 & Mumbai & India & Asia \\
\hline 64 & Munich & Germany & Western Europe \\
\hline 65 & Nairobi & Kenya & Africa \\
\hline 66 & New Delhi & India & Asia \\
\hline 67 & New York & United States & North America \\
\hline 68 & Osaka-Kobe & Japan & Asia \\
\hline 69 & Oslo & Norway & Western Europe \\
\hline 70 & Paris & France & Western Europe \\
\hline
\end{tabular}


Table 1.3: (Continued)

\begin{tabular}{|c|c|c|c|}
\hline No. & City & Country & Region \\
\hline 71 & Perth & Australia & Australasia \\
\hline 72 & Pittsburgh & United States & North America \\
\hline 73 & Prague & Czech Republic & Eastern Europe \\
\hline 74 & Pretoria & South Africa & Africa \\
\hline 75 & Qingdao & China & Asia \\
\hline 76 & Quito & Ecuador & South America \\
\hline 77 & Reykjavik & Iceland & Western Europe \\
\hline 78 & Rio de Janeiro & Brazil & South America \\
\hline 79 & Rome & Italy & Western Europe \\
\hline 80 & San Francisco & United States & North America \\
\hline 81 & Santiago & Chile & South America \\
\hline 82 & Sao Paulo & Brazil & South America \\
\hline 83 & Seattle & United States & North America \\
\hline 84 & Seoul & South Korea & Asia \\
\hline 85 & Shanghai & China & Asia \\
\hline 86 & Shenzhen & China & Asia \\
\hline 87 & Singapore & Singapore & Asia \\
\hline 88 & Sofia & Bulgaria & Eastern Europe \\
\hline 89 & St Petersburg & Russia & Eastern Europe \\
\hline 90 & Stockholm & Sweden & Western Europe \\
\hline 91 & Suzhou & China & Asia \\
\hline 92 & Sydney & Australia & Australasia \\
\hline 93 & Taipei & Taiwan, China & Asia \\
\hline 94 & Tel Aviv & Israel & Asia \\
\hline 95 & Tianjin & China & Asia \\
\hline 96 & Tokyo & Japan & Asia \\
\hline 97 & Toronto & Canada & North America \\
\hline 98 & Vancouver & Canada & North America \\
\hline 99 & Vienna & Austria & Western Europe \\
\hline 100 & Warsaw & Poland & Eastern Europe \\
\hline 101 & Washington DC & United States & North America \\
\hline 102 & Wellington & New Zealand & Australasia \\
\hline 103 & Zurich & Switzerland & Western Europe \\
\hline
\end{tabular}

Source: Asia Competitiveness Institute 
the chapter outlines the trends of Cost of Living Index and Ranking for Expatriates in each of the 103 cities over the period 2005-2014.

Chapter 5 provides the corresponding analyses for cost of living, wages and purchasing power indices and rankings for ordinary residents. The latest results based on 2014 data for the top- and bottom-25 percent cities are first reported. Region-specific observations about the rankings then follow, before the discussion on the trends of cost of living, wages and purchasing power for ordinary residents in each among the 103 cities between 2005 and 2014 . When conducting the trend analysis, we split the study period into two sub-periods: from 2005 to 2010 and from 2011 to 2014. This is because the Cost of Living Index for Ordinary Residents, which is also used in the computation of the Purchasing Power Index for Ordinary Residents, is constructed using data from two different rounds of the World Bank International Comparison Program survey in 2005 and 2011.

Chapter 6 discusses the relationships between cost of living, purchasing power and liveability. We leverage on the ACI Global Liveable Cities Index (GLCI) research which measures liveability from ordinary residents' perspective. ${ }^{20}$ We first plot the Cost of Living Index for Ordinary Residents against this index. Next, we regress the cost of living index against the GLCI, controlling for cities' wage levels and population. For purchasing power, scatterplots between the Purchasing Power Index for Ordinary Residents and the GLCI are also constructed. As a case study, we also compare the cost of living, purchasing power and liveability between Singapore as a city-state and Kuala Lumpur, the capital of Malaysia, linking these with Singapore's and Malaysia's national economic competitiveness in order to explain the migration of Malaysians, especially the skilled workforce, to Singapore. Finally, the chapter ends with some concluding remarks and tentative policy implications.

\section{References}

Blackorby, Charles and R. Robert, Russell. 1978. "Indices and Subindices of the Cost of Living and the Standard of Living”, International Economic Review, 19(1): 229-240.

Chew, Joey, Sam Ouliaris, and Siang Meng Tan. 2011. "Exchange Rate Pass-Through over the Business Cycle in Singapore.” IMF Working Paper No. 11/141, International Monetary Fund (IMF), Washington DC.

Diewert, Walter E. and Alice O. Nakamura, eds. 1993. Essays in Index Number Theory. Vol. 1. New York: North Holland.

Florida, Richard. 2002. Cities and the Creative Class, 1st edn. New York: Routledge.

Hasan, Lubna. 2007. "On Measuring the Complexity of Urban Living." Munich Personal REPEC Archive (MPRA) No. 7413, March.

Hill, Peter. 1997. "The Measurement of Inflation and Changes in the Cost of Living." Prepared for the Conference of European Statisticians, Joint ECE/ILO Meeting on Consumer Price Indices, Geneva, November 24-27.

Konus, A. A. 1939. "The Problem of the True Index of the Cost of Living." Econometrica, 7(January): $10-29$.

${ }^{20}$ See Chapter 5 in Tan et al. (2017, forthcoming). 
Ministry of Manpower. 2009. Report on Labour Force in Singapore, 2009. Singapore: Ministry of Manpower.

Pollack, Robert A. 1989. The Theory of the Cost of Living Index. New York: Oxford University Press.

Singapore Tourism Board. 2013. STB Market Insights: India. Singapore: Singapore Tourism Board.

Tan, Khee Giap and Qingyang Gu. 2011. “数据、事实和翏误” [Figures, facts and fallacies], Lianhe Zaobao, 3 May, p. 20.

Tan, Khee Giap, and Minh Khuong Vu. 2011. "Figures, facts and fallacies." The Straits Times, 3 May: A35.

Tan, Khee Giap, Kong Yam Tan, Randong Yuan, and Le Phuong Anh Nguyen. 2015. 2014 Annual Indices for Expatriates and Ordinary Residents on Cost of Living, Wages and Purchasing Power for World's Major Cities. Singapore: World Scientific.

Tan, Khee Giap and Nguyen Trieu Duong Luu. 2016, "Measuring Cost of Living for Ordinary Residents in Cities: A New Index." Business and Management Studies, 2(3): 52-77.

Tan, Khee Giap, Tongxin Nie, and Shinae Baek. 2017 (forthcoming). 2015 Greater China Liveable Cities Index: Ranking Analysis, Simulation and Policy Evaluation. Singapore: Whioce Publishing.

The World Bank. 2016. “Urban Development Overview.” Available at http://www.worldbank.org/en/topic/ urbandevelopment/overview (last accessed on February 6, 2017).

Triplett, Jack E. 2001. "Should the Cost-of-living Index Provide the Conceptual Framework for a Consumer Price Index?” The Economic Journal, 111(472): 311-334.

UBS Wealth Management Research Department. 2009. The UBS Prices and Earnings Report 2009: A Global Purchasing Power Comparison. Zurich: UBS.

United Nations. 2014. "World's population increasingly urban with more than half living in urban areas." Available at http://www.un.org/en/development/desa/news/population/world-urbanization-prospects2014.html (last accessed on February 6, 2017). 